Bangladesh J. Bot. 41(2): 131-134, 2012 (December)

\title{
EFFECT OF NPK FERTILIZERS ON GROWTH, YIELD AND YIELD ATTRIBUTES OF OKRA (ABELMOSCHUS ESCULENTUS (L.) MOENCH.)
}

\author{
MA RAHMAN* AND FERDOUSI AKTER \\ Department of Botany, University of Chittagong, Chittagong-4331, Bangladesh
}

Key words: Okra, NPK fertilizers, Growth, Yield

\begin{abstract}
Five different doses of NPK fertilizers, viz. $\mathrm{T}_{0}(0 \mathrm{~N} 0 \mathrm{P} 0 \mathrm{~K}), \mathrm{T}_{1}(1 \mathrm{~N} 1 \mathrm{P} 1 \mathrm{~K}), \mathrm{T}_{2}(0 \mathrm{~N} 1 \mathrm{P} 1 \mathrm{~K}), \mathrm{T}_{3}(1 \mathrm{~N} 0 \mathrm{P} 1 \mathrm{~K})$ and $\mathrm{T}_{4}(1 \mathrm{~N} 1 \mathrm{P} 0 \mathrm{~K})$ were applied and the growth, yield and yield attributes of okra were studied. The length of main stem, number of nodes and leaves were maximum at $T_{1}$. The fresh weight, length, circumference, diameter per fruit and yield per plant were the highest at $T_{1}$. The carotenoid content of leaves and vitamin $C$ contents of fruits were maximum at $T_{1}$. The total NPK concentration of both plants and fruits were the highest at $T_{3}$.
\end{abstract}

\section{Introduction}

Okra is a popular vegetable crop grown from seed. It is mainly cultivated in Kharif season in Bangladesh. Okra is a poor yielder of about 3.0 t/ha (BBS 2000), which is very low compared to other neighboring country like India (6.12 t/ha) and other developing countries (7.12 t/ha) of the world (Yamaguchi 1998).

The low yield of okra in Bangladesh may be due to improper use of fertilizers and poor management practices. Some workers used NPK fertilizers for the increase of growth, yield and yield attributes of okra. Significant increase in the growth and yield of okra was observed after the application of N and or NPK (Katung et al. 1996). Firoz (2009) reported that the highest yield (16.73 t/ha) was obtained after the application of $100 \mathrm{~kg} \mathrm{~N} / \mathrm{ha}$ which was statistically identical to $120 \mathrm{~kg} \mathrm{~N} / \mathrm{ha}$. He also obtained the highest yield (15.77 t/ha) from $120 \mathrm{~kg} \mathrm{P}_{2} \mathrm{O}_{5} /$ ha. Philip et al. (2010) reported that spacing of $90 \times 30 \mathrm{~cm}$ and application of NPK fertilizers $150 \mathrm{~kg} / \mathrm{ha}(22.5 \mathrm{~kg}$ $\mathrm{N}, 22.5 \mathrm{~kg} \mathrm{P}_{2} \mathrm{O}_{5}$ and $22.5 \mathrm{~kg} \mathrm{~K}_{2} \mathrm{O}_{5}$ ) gave the highest yield of okra.

Reports on the effect of NPK fertilizers on the growth, yield and yield components of okra are rare in Bangladesh. Hence, in the present investigation the effect of different doses of NPK fertilizers on growth, yield and yield attributes of okra was studied.

\section{Materials and Methods}

Seeds of okra (Abelmoschus esculentus (L.) Moench.) var. ARKA ANAMIKA were collected from local nursery and sown in the experimental field. The field was ploughed, cross ploughed and leveled properly and divided into 15 plots, each measuring $2 \times 1 \mathrm{~m}$ with $50 \mathrm{~cm}$ space between two plots. Each plot contained three rows and every row contained four hills. The spacing between row to row and hill to hill was $60 \mathrm{~cm}$ and $45 \mathrm{~cm}$, respectively. The field design was maintained trireplicated Randomized Complete Block Design (RCBD).

Different doses of fertilizers applied per plot are as follows: $\mathrm{T}_{0}$ (ONOPOK) - two kg cow-dung were applied during land preparation. $\mathrm{T}_{1}(1 \mathrm{~N} 1 \mathrm{P} 1 \mathrm{~K})$ - (a) $2 \mathrm{~kg}$ cow-dung, $65 \mathrm{~g}$ urea, $150 \mathrm{~g}$ TSP and $105 \mathrm{~g}$ MP were applied during land preparation, (b) $65 \mathrm{~g}$ urea were applied after 25 days of sowing. $\mathrm{T}_{2}(0 \mathrm{~N} 1 \mathrm{P} 1 \mathrm{~K})-2 \mathrm{~kg}$ cow-dung, $150 \mathrm{~g}$ TSP and $105 \mathrm{~g}$ MP were applied during land preparation, $\mathrm{T}_{3}(1 \mathrm{~N} 0 \mathrm{P} 1 \mathrm{~K})$ - (a) $2 \mathrm{~kg}$ cow-dung, $65 \mathrm{~g}$ urea and $105 \mathrm{~g}$ MP were applied during land

*Author for correspondence: <arahmanbot42@yahoo.com>. 
preparation, (b) 65 g urea were applied after 25 days of sowing. $\mathrm{T}_{4}$ (1N1P0K) - (a) $2 \mathrm{~kg}$ cow-dung, $65 \mathrm{~g}$ urea and $150 \mathrm{~g}$ TSP were applied during land preparation, (b) $65 \mathrm{~g}$ urea were applied after 25 days of sowing.

Two seeds were sown per hill. After germination one uniform seedling was kept in each hill and rests were thinned out. Total number of seedlings per plot was 12 . Watering, weeding, mulching and other cultural practices were done as and when required. The length of main stem, number of nodes and leaves and number of branches were recorded at the opening of first flower and continued at 15 days interval till final harvest. The final data (addition of all counts) were used in the tables. The fruits of okra of all the treatments were harvested at marketable stage. Before harvesting the number of fruits per plant was recorded. The number of fruits per plant, fresh weight, length, circumference and diameter of fruits of each treatment were recorded just immediately after harvest. The yield per plant was calculated by multiplying the number of fruits per plant and fresh weight per fruit.

The plants were finally harvested after five months of sowing. After harvesting the fresh weight of whole plant (stem and leaf ) was weighed. Then the plants were chopped and dried in an oven at $65^{\circ} \mathrm{C}$ till a constant dry weight was obtained. For chemical analysis $100 \mathrm{~g}$ of fresh plant (stem and leaf) and fruit samples were dried in an oven at $65^{\circ} \mathrm{C}$. Then ground in an electric grinder and made into powder (60 meshed sieves) and stored in air-tight containers. Dried powder of plant and fruit samples was digested following modified micro-Kjeldahl method. N, P and $\mathrm{K}$ were determined as described by Jackson (1973). Chlorophyll $a, b$ and carotenoid contents of fresh leaves of okra at the onset of flowering were determined spectrophotometically and calculated following Wettstein (1957). Vitamin C of fresh fruit sample was determined following Pleshkov (1976).

\section{Results and Discussion}

The length, number of branches and length of branches increased significantly in almost all the treatments from $T_{0}$ and the highest values were in $T_{1}, T_{4}$ and $T_{1}$, respectively (Table 1 ). The number of nodes and leaves of main vine and branches and total number of nodes and leaves per plant also increased significantly in all the treatments from $T_{0}$ and maximum values were in $T_{1}, T_{3}$ and $\mathrm{T}_{1}$, respectively (Table 1 ).

Table 1. Effect of different doses of NPK fertilizers on length per plant, number of branches per plant, length per branch, and number of nodes and leaves per plant of okra.

\begin{tabular}{ccccccc}
\hline Treatments & Height/ & Number of & Length/ & \multicolumn{3}{c}{ Number of nodes and leaves/plant } \\
\cline { 5 - 7 } & plant $(\mathrm{cm})$ & branches/plant & branch $(\mathrm{cm})$ & Main stem & Branch & Total \\
\hline $\mathrm{T}_{0}$ & $22.83 \mathrm{a}$ & $1.00 \mathrm{a}$ & $13.67 \mathrm{a}$ & $7.67 \mathrm{a}$ & $5.67 \mathrm{a}$ & $13.34 \mathrm{a}$ \\
$\mathrm{T}_{1}$ & $\mathbf{6 3 . 1 1 e}$ & $2.33 \mathrm{bc}$ & 32.33d & $\mathbf{1 8 . 0 0 d}$ & $11.00 \mathrm{~b}$ & 29.00c \\
$\mathrm{T}_{2}$ & $40.00 \mathrm{~b}$ & $2.00 \mathrm{~b}$ & $15.00 \mathrm{~b}$ & $10.67 \mathrm{~b}$ & $12.33 \mathrm{c}$ & $23.00 \mathrm{~b}$ \\
$\mathrm{~T}_{3}$ & $47.00 \mathrm{~d}$ & $2.67 \mathrm{~cd}$ & $16.25 \mathrm{~b}$ & $10.33 \mathrm{~b}$ & $\mathbf{1 3 . 0 0 c}$ & $23.33 \mathrm{~b}$ \\
$\mathrm{~T}_{4}$ & $45.03 \mathrm{c}$ & $\mathbf{3 . 0 0 d}$ & $23.00 \mathrm{c}$ & $12.33 \mathrm{c}$ & $10.00 \mathrm{~b}$ & $22.33 \mathrm{~b}$ \\
\hline
\end{tabular}

Mean in a column followed by same letter do not differ significantly at $5 \%$ level.

The number of fruits per plant increased highly significantly in all the treatments from $\mathrm{T}_{0}$ and the highest number of fruits per plant was found in $T_{2}$. The fresh weight, length, circumference, diameter of fruit and yield per plant also increased significantly in all the treatments from $T_{0}$ and maximum values were obtained in $\mathrm{T}_{1}$ for all the cases (Table 2). The yield per plant increased with the increase of fresh weight per fruit and a significant positive correlation $(r=0.91)$ was found 
between fresh weight per fruit and yield per plant. The increase of yield of okra of the present investigation due to N application was found consistent with the finding of Katung et al. (1996), Hooda et al. (1980), Mani and Ramanathan (1980), Majanbu et al. (1985) and Singh (1995). The increase of yield of okra due to P and NPK application of the investigation corroborates other studies (Sharma and Yadev 1976, Firoz 2009). The combined effect of NPK fertilizers for the increase of yield of okra in the present investigation was found consistent with the findings of Ahmed and Tullock-Reid (1986) and Philip et al. (2010).

Table 2. Effect of different doses of NPK fertilizers on number of fruits per plant, fresh weight per fruit, length, circumference, diameter per fruit and yield per plant of okra.

\begin{tabular}{ccrcccc}
\hline Treatments & $\begin{array}{c}\text { Number of } \\
\text { fruits/ plant }\end{array}$ & $\begin{array}{c}\text { Fresh wt./ } \\
\text { fruit }(\mathrm{g})\end{array}$ & $\begin{array}{c}\text { Length/ } \\
\text { fruit }(\mathrm{cm})\end{array}$ & $\begin{array}{c}\text { Circumference/ } \\
\text { fruit }(\mathrm{cm})\end{array}$ & $\begin{array}{c}\text { Diameter/ } \\
\text { fruit }(\mathrm{cm})\end{array}$ & $\begin{array}{c}\text { Yield/ plant } \\
(\mathrm{g})\end{array}$ \\
\hline $\mathrm{T}_{0}$ & $1.80 \mathrm{a}$ & $5.87 \mathrm{a}$ & $7.15 \mathrm{a}$ & $4.20 \mathrm{a}$ & $1.30 \mathrm{a}$ & $10.56 \mathrm{a}$ \\
$\mathrm{T}_{1}$ & $6.00 \mathrm{~d}$ & $\mathbf{1 5 . 2 0 e}$ & $\mathbf{1 5 . 2 0 e}$ & $\mathbf{6 . 0 0 e}$ & $\mathbf{1 . 9 0 b}$ & $91.20 \mathrm{~d}$ \\
$\mathrm{~T}_{2}$ & $\mathbf{8 . 0 0 e}$ & $11.59 \mathrm{~d}$ & $11.34 \mathrm{~d}$ & $5.10 \mathrm{~d}$ & $1.67 \mathrm{ab}$ & $\mathbf{9 2 . 7 2 d}$ \\
$\mathrm{T}_{3}$ & $5.00 \mathrm{c}$ & $10.10 \mathrm{c}$ & $9.48 \mathrm{c}$ & $4.80 \mathrm{c}$ & $1.53 \mathrm{ab}$ & $50.50 \mathrm{c}$ \\
$\mathrm{T}_{4}$ & $4.00 \mathrm{~b}$ & $9.89 \mathrm{~b}$ & $8.53 \mathrm{~b}$ & $4.50 \mathrm{~b}$ & $1.47 \mathrm{a}$ & $39.56 \mathrm{~b}$ \\
\hline
\end{tabular}

Mean in a column followed by same letter do not differ significantly at $5 \%$ level.

The chlorophyll $a$ content of leaves was significantly higher in all the treatments from $\mathrm{T}_{0}$ except $T_{2}$. The highest value was at $\mathrm{T}_{4}$ followed by $\mathrm{T}_{1}, \mathrm{~T}_{3}, \mathrm{~T}_{2}$ and $\mathrm{T}_{0}$. The chlorophyll $b$ contents of leaves increased significantly in all the treatments except $T_{3}$ and maximum value was in $T_{4}$ (Table 3). Carotenoid contents also increased significantly in all the treatments and the highest carotenoid content was in $\mathrm{T}_{1}$. The total pigment content was obtained maximum in $\mathrm{T}_{4}$ followed by $\mathrm{T}_{1}, \mathrm{~T}_{3}, \mathrm{~T}_{2}$ and $\mathrm{T}_{0}$ (Table 3).

Table 3. Effect of different doses of NPK fertilizers on chlorophyll $a, b$, carotenoids and total pigment contents of fresh leaves of okra at the onset of flowering.

\begin{tabular}{ccccc}
\hline Treatments & $\begin{array}{c}\text { Chlorophyll } a \\
(\mathrm{mg} / \mathrm{g})\end{array}$ & $\begin{array}{c}\text { Chlorophyll } b \\
(\mathrm{mg} / \mathrm{g})\end{array}$ & $\begin{array}{c}\text { Carotenoid } \\
(\mathrm{mg} / \mathrm{g})\end{array}$ & $\begin{array}{c}\text { Total pigment } \\
(\mathrm{mg} / \mathrm{g})\end{array}$ \\
\hline $\mathrm{T}_{0}$ & $3.06 \mathrm{a}$ & $1.20 \mathrm{a}$ & $1.91 \mathrm{~b}$ & $6.17 \mathrm{a}$ \\
$\mathrm{T}_{1}$ & $4.21 \mathrm{c}$ & $1.89 \mathrm{c}$ & $\mathbf{2 . 2 8 d}$ & $8.38 \mathrm{c}$ \\
$\mathrm{T}_{2}$ & $3.81 \mathrm{~b}$ & $1.35 \mathrm{~b}$ & $1.71 \mathrm{a}$ & $6.87 \mathrm{a}$ \\
$\mathrm{T}_{3}$ & $4.15 \mathrm{c}$ & $1.29 \mathrm{~b}$ & $1.87 \mathrm{~b}$ & $7.31 \mathrm{~b}$ \\
$\mathrm{~T}_{4}$ & $\mathbf{4 . 5 1 d}$ & $\mathbf{1 . 9 0 c}$ & $2.06 \mathrm{c}$ & $\mathbf{8 . 4 7 c}$ \\
\hline
\end{tabular}

Mean in a column followed by same letter do not differ significantly at $5 \%$ level.

The NPK concentration of plants and fruits were found different in different treatments of the present investigation. The $\mathrm{N}$ concentration of both plants and fruits were found significantly higher in all the treatments from $\mathrm{T}_{0}$ and the maximum value was obtained in $\mathrm{T}_{3}$. The $\mathrm{P}$ concentration of plants also increased significantly in all the treatments and the highest $\mathrm{P}$ concentration was in $T_{1}$ but the $P$ concentration of fruits was found maximum in $T_{3}$ and the lowest value was in $\mathrm{T}_{4}$. The $\mathrm{K}$ concentration of plants was found significantly higher in all the treatments except in $\mathrm{T}_{4}$. The $\mathrm{K}$ concentration of fruits though found higher in most of the treatments from control but the differences were not significant. The total NPK concentration of plants and fruits increased significantly from $T_{0}$ in all the treatments and highest values were in $T_{3}$ (Table 4). 
The vitamin $\mathrm{C}$ contents of fruits were not found similar in the different treatments. The maximum vitamin $C$ content was obtained in $T_{1}(26.4 \mathrm{mg} / 100 \mathrm{~g})$ followed by $T_{2}, T_{3}, T_{4}$ and $T_{0}$ (Table 4).

Table 4. Effect of different doses of NPK fertilizers on N, P, K concentrations of plants and fruits and vitamin $C$ contents fruits of okra.

\begin{tabular}{|c|c|c|c|c|c|c|c|c|c|}
\hline \multirow{3}{*}{ Treatments } & \multicolumn{8}{|c|}{$\mathrm{N}, \mathrm{P}$ and $\mathrm{K}$ concentrations (g\% of dry weight basis) } & \multirow{3}{*}{$\begin{array}{l}\text { Vitamin C } \\
\text { (mg/100g) }\end{array}$} \\
\hline & \multicolumn{2}{|c|}{$\mathrm{N}$} & \multicolumn{2}{|c|}{$\mathrm{P}$} & \multicolumn{2}{|c|}{$\mathrm{K}$} & \multicolumn{2}{|c|}{ Total } & \\
\hline & Plants & Fruits & Plants & Fruits & Plants & Fruits & Plants & Fruits & \\
\hline $\mathrm{T}_{0}$ & $1.40 \mathrm{a}$ & $2.00 \mathrm{a}$ & $1.57 \mathrm{a}$ & $1.88 \mathrm{ab}$ & $0.64 a$ & 1.40 & 3.61a & $5.28 \mathrm{a}$ & $20.30 \mathrm{a}$ \\
\hline $\mathrm{T}_{1}$ & $2.03 c$ & $2.87 \mathrm{c}$ & $2.05 e$ & $1.93 a b$ & $1.16 \mathrm{c}$ & 1.48 & $5.24 \mathrm{c}$ & $6.28 c$ & 24.60d \\
\hline $\mathrm{T}_{2}$ & $1.84 \mathrm{~b}$ & $3.22 \mathrm{~d}$ & $2.00 \mathrm{~d}$ & $2.08 b$ & $1.37 d$ & 1.40 & $5.21 \mathrm{c}$ & $6.70 \mathrm{~d}$ & $23.80 \mathrm{c}$ \\
\hline $\mathrm{T}_{3}$ & 3.08e & 3.32e & $1.93 c$ & $2.16 b$ & $1.13 c$ & 1.43 & $6.14 d$ & 6.91e & $23.80 \mathrm{c}$ \\
\hline $\mathrm{T}_{4}$ & $2.52 \mathrm{~d}$ & $2.66 \mathrm{~b}$ & $1.76 \mathrm{~b}$ & $1.72 \mathrm{a}$ & $0.75 b$ & 1.43 & $5.03 \mathrm{~b}$ & $5.81 b$ & $22.00 \mathrm{~b}$ \\
\hline
\end{tabular}

Mean followed by same letter(s) did not differ significantly at $5 \%$ level.

From the above discussion it may be concluded that the growth, yield and yield attributes of okra were highest in $T_{1}$ where balanced dose of NPK fertilizers was applied. So, $T_{1}$ may be recommended for the growers for better yield of okra.

\section{References}

Ahmed N and Tullock-Reid LT 1986. The combined effect of NPK fertilizers for the increase of yield of okra Agron. J. 60: 353-356.

BBS (Bangladesh Bureau of Statistics) 2000. Monthly Statistical Bulletin of Bangladesh (October). Bangladesh Bureau of Statistics, Ministry of Planning. Government of the People's Republic of Bangladesh, Dhaka.

Firoz ZA 2009. Impact of nitrogen and phosphorus on the growth and yield of okra (Abelmoschus esculentus (L.) Moench.) in hill slope condition. Bangladesh J. Agril. Res. 34(4): 713-722.

Hooda RS, Pandita ML and Sidhu AS 1980. Studies on the effect of nitrogen and phosphorus on growth and green pod yield of okra. Haryanra J. Hort. Sci. 9: 180-183.

Jackson ML 1973. Soil Chemical Analysis. Prentice Hall of India.

Katung MD, Olanrewaju JD, Gupta US and Kureh I 1996. Fruit and seed yields of okra as influenced by farmyard manure and nitrogen fertilizer. In: Proc. 14th HORTSON Cent; Ago - Iwoye, 1-4 April, 1996.

Majanbu IS, Ogunlela VB, Ahmed MK and Olarewarju JD 1985. Response of two okra varieties to fertilizers on the yield and yield components as influenced by nitrogen and phosphorus application. Fert. Res. 6(3): 257-267.

Mani S and Ramnathan KM 1980. Effect of nitrogen and phosphorus on the yield of bhindi fruits. South Indian Hort. 20: 136-138.

Philip CB, Sajo AA and Futuless KN 2010. Effect of spacing and NPK fertilizer on the yield and yield components of okra (Abelmoschus esculentus (L. Moench.) in Mubi, Adamawa State, Nigeria. J. Agron. 9: 131-134.

Pleshkov BP 1976. Practical Methods of Plant Biochemistry. Moscow (Russ.). pp. 106.

Sharma BM and Yadev JPS 1976. Availability of phosphorus to grain as influenced by phosphatic fertilization and irrigation. Indian J. Agric. Sci. 46: 205-210.

Singh IP 1995. Effect of various doses of nitrogen on seed yield and quality of okra. Ann. Agril. Res. 16(2): 227-229.

Wettstein D 1957. Formula of chlorophyll determination. Exp. Cell. Res. 12(3):427-487.

Yamaguchi M 1998. World Vegetables: Principles, production and nutritive values. Van Nostrand Reinhold. New York, USA. p. 415.

(Manuscript received on 3 April, 2012; revised on 2 May, 2012) 